\title{
PENERAPAN FLIPPED CLASSROOM MODEL DALAM PEMBELAJARAN IDENTIFIKASI RISIKO PADA DIKLAT MANAJEMEN RISIKO
}

\author{
Mustofa Kamal \\ kamalopek@gmail.com \\ Pusdiklatwas BPKP
}

\begin{abstract}
This action research aims to assess the effectiveness of the Flipped Classroom model in risk identification learning. Risk identification subject is part of the Training of Risk Management. Models are chosen with consideration; the training participants are not familiar with risk identification and are always close to gadgets. The research method uses qualitative and quantitative. Learning effectiveness was assessed by trainer quantitatively, pre post test, and qualitatively, observations of two cycles of 64 participants from indonesian republic police, in 2 different timing class. Learning effectiveness was assessed also by participants through online surveys. The results showed that there was an increase in understanding of risk identification through an significant increasing in the average values in the both cycles. But, the increasing in second cycle, 1,20, are higher from first cycles, 0,70. While the results of the observation showed that the good activity of participants in study and discussion. In the other hand, a qualitative online assessment of $40,63 \%$ of participants shows $80,77 \%$ of participants asses the learning proses rated very well and $19,23 \%$ of participants rated it well.
\end{abstract}

Keywords: flipped classroom model, risk identification.

ABSTRAK: Penelitian tindakan ini bertujuan untuk menilai efektivitas flipped classroom model dalam pembelajaran identifikasi risiko. Mata diklat identifikasi risiko merupakan bagian dari Materi Pembelajaran pada Pelatihan Manajemen Risiko. Model dipilih dengan mempertimbangkan latar belakang peserta yang relatif kurang terbiasa dengan pendokumentasian risiko, dan selalu akrab dengan gadget. Metode penelitiannya menggunakan kualitatif dan kuantitatif. Efektivitas pembelajaran dinilai oleh trainer secara kuantitatif melalui pre post test, dan secara kualitatif berupa pengamatan aktivitas di 2 siklus dari 64 peserta diklat, dari Kepolisian Republik Indonesia, di 2 kelas dalam waktu yang berbeda. Efektivitas pembelajaran juga dikonfirmasi kepada peserta diklat melalui survai online. Hasil penelitian menunjukkan bahwa ada peningkatan pemahaman identifikasi risiko melalui peningkatan nilai rata-rata pre test ke post test yang signifikan di 2 siklus tersebut. Namun peningkatan nilai rata-rata di siklus yang kedua, 1,27, lebih besar dibandingkan dengan siklus yang pertama, 0,76. Sedangkan hasil pengamatan menunjukkan bahwa peserta aktif dalam mengerjakan latihan dan diskusi atau tanya jawab. Di sisi lain, penilaian kualitatif dari 40,63\% peserta secara online menunjukkan bahwa; 80,77\% peserta menilai pelaksanaan pembelajaran telah berjalan sangat baik dan 19,23\% peserta menilai baik. Kata kunci: flipped classroom model, identifikasi risiko. 


\section{PENDAHULUAN} Pendidikan dan pelatihan (diklat)
bertujuan untuk pengetahuan, keterampilan, dan perubahan sikap/perilaku peserta pada tingkat kompetensi tertentu sesuai dengan perannya. Salah satu diklat teknis yang dilaksanakan oleh pusat pendidikan dan pelatihan pengawasan, Badan Pengawasan Keuangan dan Pembangunan (Pusdiklatwas BPKP) adalah Diklat Manajemen Risiko (MR). Ada beberapa materi pada diklat ini, salah satunya adalah identifikasi risiko. Hasil belajar yang harus diraih oleh peserta adalah peserta mampu melakukan identifikasi risiko di organisasinya. Metode pembelajaran yang ada di modul manajemen risiko berupa ceramah, diskusi, tanya jawab dan latihan. Informasi latihan yang ada di modul buku kerja menggunakan contoh pemerintah daerah (BPKP, 2014).

Sementara itu, peserta diklat MR merupakan para pegawai Kepolisian Republik Indonesia (POLRI) yang berbeda kultur kerjanya dengan pemda. Selain itu, peserta juga akrab dengan gadget dan tidak terbiasa dengan aktivitas dan pendokumentasian identifikasi risiko. Untuk mencapai efekftivitas pembelajaran pada peserta dengan kondisi tersebut, peneliti mempertimbangkan untuk menggunakan flipped classroom model.

Model pembelajaran flipped classroom dapat memotivasi guru dan siswa untuk memanfaatkan teknologi informasi dan komunikasi secara benar untuk proses pembelajaran, melatih kemandirian belajar peserta didik, serta dapat digunakan untuk meningkatkan kepercayaan diri, aktivitas dan hasil belajar (Pratiwi dkk, 2017)

Dalam flipped classroom, model instruksi konvensional dibuat menjadi "flipped" (Bermann \& Sams, 2012 dalam
The Benjamin Center, 2016). Peserta didik membuka/mempelajari materi diluar kelas, biasanya melalui membaca atau menonton video pembelajaran. Kemudian saat di kelas dilanjutkan dengan pemecahan masalah, diskusi atau tanya jawab (Brame, 2013, p. 1 dalam The Benjamin Center, 2016). Dengan kata lain, model flipped classroom memberikan apa yang umumnya di lakukan di kelas dan apa yang umumnya dilakukan sebagai pekerjaan rumah kemudian dibalik atau ditukar. Peserta didik membaca materi, melihat video pembelajaran sebelum mereka datang ke kelas (Damayanti dan Sutama, 2016). Tantangan flipped classroom adalah butuh kesediaan meluangkan waktu, usaha dan komitmen dari pengajar dan peserta didik (The Benjamin Center, 2016).

Ada beberapa penelitian sebelumnya tentang penggunaan flipped classroom. Damayanti dan Sutama (2016) membuktikan bahwa penggunaan flipped classroom efektif meningkatkan sikap dan keterampilan belajar matematika di SMK Negeri 1 Gedangsari Gunung Kidul Yogyakarta.

Sedangkan Pratiwi dkk (2017) membuktikan ada perbedaan signifikan pengaruh antara model flipped classroom dengan model kelas konvensional dalam pembelajaran MIPA di SMA N 8 Pontianak.

Flipped classroom model dalam penelitian ini akan diterapkan pada jenis kelas yang berbeda dengan yang di Damayanti dan Sutama (2016) dan Pratiwi dkk (2017). Penelitian ini menggunakan objek kelas dalam pendidikan non formal yaitu diklat MR pegawai POLRI, Sehingga ada pertanyaan penelitian;

1. Bagaimana penerapan flipped classroom model dalam pembelajaran identifikasi risiko di Diklat MR POLRI?, dan 
2. Bagaimana efektivitas flipped classroom model dalam pembelajaran tersebut?.

Sedangkan tujuan penelitian ini adalah untuk mengetahui praktik penerapan dan efektivitas flipped classroom model dalam pembelajaran identifikasi risiko. Hasil penelitian ini diharapkan bermanfaat bagi pengembangan metode pembelajaran identifikasi risiko dalam Diklat MR.

Berdasarkan penjelasan di atas, dikembangkan hipotesis sebagai berikut:

Ho : Pembelajaran Flipped Classroom model tidak berpengaruh positif dan signifikan terhadap pembelajaran identifikasi risiko.

$\mathrm{Ha}$ : Pembelajaran Flipped Classroom model berpengaruh positif dan signifikan terhadap pembelajaran identifikasi risiko.

\section{METODOLOGI}

Penelitian ini merupakan penelitian tindakan dengan metode kualitatif dan kuantitatif. Data yang digunakan penelitian kualitatif adalah data primer dan sekunder. Data primer berupa, antara lain, data verbal dari informan yang berkenaan dengan penelitian. Data sekunder berupa data yang diperoleh dari dokumen grafis dan lain-lain yang dapat memperkaya data primer. Sedangkan penelitian kuantitatif menuntut penggunaan angka, mulai dari pengumpulan data, penafsiran dan penampilan hasilnya. Analisis data dengan rumus statistik, dapat juga hanya statistik sederhana dalam bentuk rerata, simpangan baku, tabulasi silang, tabel, bagan dan grafik (Arikunto, 2014). Signifikansi hasil pembelajaran diuji dengan $T$ paired test atas hasil pre-post test (Hidayat, 2013).

Prosedur

penelitiannya

menggunakan siklus yang terdiri dari perencanaan, pengambilan tindakan, pengamatan dan refleksi (LAN 2007). Ada 2 siklus yang akan diterapkan di 2 kelas yang berbeda waktu. Objeknya adalah 64 peserta diklat MR, pegawai POLRI, di Pusdiklatwas BPKP. Di kelas pertama, ada 30 peserta diklat MR pada tanggal 20 Februari 2019 dan ada 34 peserta diklat MR pada tanggal 13 Maret 2019 kelas kedua. Tahap penelitiannya sebagai berikut:

Tabel 1. Tahap Penelitian Tindakan

Tahap Siklus $1 \quad$ Siklus 2

1. Pengiriman video Sama dg siklus

$\frac{1}{0}$
$\mathbb{0}$
$\frac{1}{0}$
$\frac{0}{0}$
$\frac{1}{0}$
0 MR kepada peserta di $\mathrm{H}-1$

2. Penyiapan soal pre-posttest dan bahan latihan

1 ditambah pertimbangan hasil refleksi siklus 1

3. Pengerjaan pretest

4. Penjelasan identifikasi risiko

Sama dg siklus

5. Pengerjaan dan 1 ditambah pembahasan penyesuaian

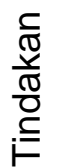
latihan

6. Pengerjaan posttest

7. Pengamatan atas aktivitas peserta

$\frac{1}{0}$
$\stackrel{0}{0}$
$\frac{0}{0}$
$\frac{0}{0}$
$\frac{1}{0}$
0 saat pengambilan tindakan

Sama dg siklus

8. Pengamatan atas pemahaman peserta

9. Efektivitas pembelajaran

10. Pendapat dan Sama dg siklus saran peserta atas pembelajaran (sumber: diolah dari LAN, 2007 dan Suharsono, 2015) 


\section{HASIL DAN PEMBAHASAN}

\section{Siklus Pertama}

\section{a. Perencanaan}

Widyaiswara mengirim video MR kepada peserta pada hari sebelumnya, tanggal 19 Februari 2019, melalui nomor HP ketua kelas. Widyaiswara memberi arahan melalui whatsapp agar video MR ditonton di sore atau malam hari, saat peserta tidak di kelas. Soal prepost tes disiapkan berupa 10 soal pilihan ganda, $70 \%$ pertanyaannya terkait substansi materi yang ada di video MR. Widyaiswara juga menyiapkan materi latihan identifikasi risiko fraud pengadaan.

\section{b. Tindakan}

Di awal pembelajaran, widyaiswara mengkonfirmasi tentang video yang telah dikirim dan telah ditonton peserta. Kemudian, 30 Peserta diklat mengerjakan pre test. Lalu, Materi identifikasi risiko dijelaskan secara singkat oleh widyaiswara. Kemudian, Peserta mengerjakan latihan secara berkelompok dan diskusi dibimbing widyaiswara. Di akhir pembelajaran, peserta mengerjakan posttest.

\section{c. Pengamatan}

Pada saat pengamatan aktivitas \& pemahaman dalam pengerjaan latihan dan diskusi menunjukkan para peserta semangat, antusias dalam diskusi. Pemahaman peserta juga nampak baik tercermin dari beberapa pertanyaan lisan dari widyaiswara dapat dijawab dengan baik.

\section{d. Refleksi}

Hasil pre post test menunjukkan ada peningkatan rata-rata nilai sebesar 0,76 , yaitu dari rata-rata nilai pre test sebesar 5,27 meningkat menjadi 6,03 saat posttest. Uji T paired menghasilkan $p$ value $=0,0155$ atau dibawah 0,05 yang berarti signifikan (Hidayat, 2013).

Kemudian $50 \%$ peserta atau 15 menjawab survai tertutup secara online. Hasilnya $73,33 \%$ atau 11 orang berpendapat bahwa pembelajaran telah berjalan sangat baik. Sisanya sebesar $26,67 \%$ atau 4 orang menilai baik. Disamping itu, ada beberapa saran dari peserta yaitu:

- Ada simulasi yang berkaitan dengan penerapan MR di Polri

- Widyaiswara sebaiknya pahami latar belakang peserta dan memberikan contoh permasalahan baik terkait administrasi maupun teknis POLRI.

\section{Siklus Kedua}

\section{a. Perencanaan}

Pengiriman video MR kepada peserta pada hari sebelumnya, tanggal 12 Maret 2019, melalui ketua kelas. Widyaiswara memberi arahan agar video MR ditonton di sore atau malam hari, saat peserta tidak di kelas. Soal prepost tes yang disiapkan sama dengan yang di siklus 1 .

Hasil refleksi siklus 1 dipertimbangkan dengan penyesuaian materi latihan berupa penggalian informasi permasalahan di POLRI secara langsung di kelas.

\section{b. Tindakan}

Widyaiswara mengkonfirmasi tentang video yang telah dikirim dan telah ditonton peserta. Namun mayoritas peserta belum menonton, sehingga widyaiswara menilai perlu memutar ulang video tersebut. Kemudian, 34 Peserta diklat mengerjakan pre test. Materi identifikasi risiko dijelaskan secara singkat oleh widyaiswara. Diskusi langsung dilakukan widyaiswara dengan menggali informasi permasalahan di POLRI. Widyaiswara langsung membimbing pengerjaan latihan identifikasi risiko secara 
terbuka ke peserta. Akhir pembelajaran, peserta mengerjakan posttest.

\section{c. Pengamatan}

Pengamatan aktivitas \& pemahaman peserta saat penggalian informasi dan pengerjaan latihan secara terbuka dan diskusi menunjukkan para peserta semangat, antusias dalam diskusi. Pemahaman peserta juga nampak baik tercermin dari sumbangsih permasalahan masa lalu yang pernah terjadi di POLRI menjadi sumber informasi identifikasi risiko. Komunikasi sirkular terjadi lebih hidup dalam proses pembelajaran.

\section{d. Refleksi}

Hasil pre-post test menunjukkan ada peningkatan rata-rata nilai sebesar 1,27 yaitu dari rata-rata nilai pre test sebesar 7,00 meningkat menjadi 8,27 saat posttest. Uji T paired menghasilkan $p$ value $=0,0000$ atau dibawah 0,05 yang berarti signifikan (Hidayat, 2013).

Kemudian 32,35\% atau 11 peserta menjawab survai tertutup secara online. Hasilnya 90,91\% atau 10 orang berpendapat bahwa pembelajaran telah berjalan sangat baik. Sisanya sebesar $9,09 \%$ atau 1 orang menilai baik. Disamping itu, ada beberapa saran dari peserta yaitu:

- perlu ada praktik langsung dan penerapan pada MR di Satker atau instansi Polri

- perbanyak film yg berhubungan POLRI, seperti orang yang kena tilang, kasus salah tangkap sehingga ada praperadilan, penegakan hukum bagi yang korupsi di POLRI.

Dari hasil kedua siklus diatas, secara umum, terjadi peningkatan nilai yang signifikan dari pre ke post test. Kemudian, dalam survai online secara keseluruhan menunjukkan bahwa ada $40,63 \%$ atau 26 peserta andil dalam feedback. Hasilnya; $80,77 \%$ atau 21 peserta menilai pelaksanaan pembelajaran telah berjalan sangat baik dan $19,23 \%$ atau 5 peserta menilai baik.

Pembahasan diatas menunjukkan bahwa Ha terbukti, yaitu Pembelajaran Flipped Classroom model berpengaruh positif dan signifikan terhadap pembelajaran identifikasi risiko.

\section{SIMPULAN}

Flipped classroom model dapat diterapkan dalam pembelajaran identifikasi risiko pada Diklat Manajemen Risiko. Penerapannya dapat melalui pengiriman materi pembelajaran berupa video MR kepada peserta di $\mathrm{H}-1$. Temuan penilitian tindakan menunjukkan bahwa penerapan flipped classroom model berpengaruh positif dan signifikan. Hal ini dapat disimpulkan bahwa pembelajaran telah efektif dan dapat menggugah partisipasi aktif peserta didik dan dapat meningkatkan pemahaman identifikasi risiko.

Hasil penelitian ini selaras dengan penelitian dari Damayanti dan Sutama (2016) dan Pratiwi dkk (2017) dalam penggunaan flipped classroom model. Implikasi penilitian ini adalah widyaiswara dapat merancang penggunaan flipped classroom untuk materi diklat yang lain. Widyaiswara juga harus lebih giat dan kreatif dalam perencanaan strategi pembelajaran untuk mencapai efektivitas pembelajaran. Hasil penelitian tindakan ini secara umum juga dapat menjadi masukan bagi para peneliti dalam pengembangan variasi dan bentuk rancangan penelitian tindakan berikutnya.

\section{KETERBATASAN PENELITIAN}

Ada keterbatasan pada penelitian tindakan ini, yaitu; 2 siklus diterapkan pada 2 objek yang berbeda sehingga suasana lahir batin 
peserta tentu juga berbeda yang kemungkinan berkonsekuensi pada inkonsistensi daya nalar peserta. Selain itu, pengamatan hanya dilakukan oleh widyaiswara atau tidak menggunakan pembanding karena minim dukungan sumber daya.

\section{DAFTAR PUSTAKA}

Arikunto Suharsimi, 2014, Prosedur Penelitian; Suatu Pendekatan Praktik, PT Rineka Cipta, Jakarta

BPKP, 2014, Manajemen Risiko Sektor Publik, Modul Diklat Teknis Substansi, Pusdiklatwas BPKP, Bogor

Damayanti H.N. dan Sutama, 2016, efektivitas flipped classroom terhadap sikap dan ketrampilan belajar matematika di SMK, Jurnal Manajemen Pendidikan - Vol. 11, No. 2, Januari 2016: 2-8

Hidayat A., 2013, Tutorial Cara Uji T Paired Dengan Excel, https://www.statistikian.com/2013/01/t -paired-excel.html diakses 16 Maret 2019

LAN, 2007, Penelitian Tindakan Kelas, Modul Diklat Calon Widyaiswara, LAN RI, Jakarta

Pratiwi A., Sahputra R., Hadi L., 2017, pengaruh model flipped classroom terhadap self-confidence dan hasil belajar siswa SMAN 8 Pontianak, Program Studi Pendidikan Kimia FKIP Untan Pontianak, diunduh tanggal 19 september 2018 pada laman https://media.neliti.com/media/publicat ions/211757-none.pdf
Suharsono A., 2015, pengembangan metode pembelajaran kompetensi non teknis planning and organizing pegawai direktorat jenderal pajak dengan permainan sundamanda, Simposium Pendidikan Tahun 2015, Jakarta, 2015

The Benjamin Center, 2016, The Flipped Classroom. An Approach to Teaching and Learning, July 2016, Essay in A 2020 vision for public education in ulster county, The Benjamin Center, Suny New Paltz Ulster County School Boards Association 